\title{
Kontrol Diri Siswa Dalam Penggunaan Facebook Pada Siswa
}

\author{
Devi Fahlevi( ${ }^{(1)}$, Samsuar(2), Zulkarnain ${ }^{(3)}$ \\ ${ }^{1}$ Bimbingan dan Konseling Islam, IAIN Langsa ${ }^{2}$ Bimbingan dan Konseling Islam, IAIN Langsa \\ ${ }^{3}$ Bimbingan dan Konseling Islam, IAIN Langsa \\ 1'devifahlevi25@gmail.com, ${ }^{2}$ samlangsa@gmail.com
}

\begin{tabular}{|c|c|}
\hline $\begin{array}{l}\text { First received: } \\
\text { 1 January } 2019\end{array}$ & $\begin{array}{c}\text { Revised: } \\
\text { 02 February } 2019\end{array}$ \\
\hline
\end{tabular}

\begin{abstract}
The use of Facebook at this time many students who cannot manage their Facebook access need to look for attention that is considered slang. The purpose of this study was to learn how to control yourself MTsN Bustanul Huda students in using Facebook. This study uses a qualitative method with the type of phenomenological study, the determination of informants about this research is determined by using purposive sampling techniques, in processing the research data using filling system techniques, the Filling System Method using research methods to find the collected data is sufficiently available so that an analysis is made. The results showed the fact of thirteen informants who were unable to control Facebook compilation, while five other informants were able to control facebook compilation. Those who are not able to control themselves in using Facebook who cannot control their behavior in Facebook access such as compilation writing their status still use bad languages, and they don't review what they wrote on their Facebook, they also still upload photos that less good is the photo by not wearing hijab.

Keywords: Self Control, Students, Facebook.
\end{abstract}

\begin{abstract}
Abstrak
Penggunaan facebook saat ini banyak siswa yang tidak mampu mengontrol dirinya ketika mengakses facebook mereka cenderung mencari perhatian yang dianggap gaul. Tujuan dari penelitian ini adalah untuk mengetahui bagaimana kontrol diri siswa MTsN Bustanul Huda dalam penggunaan facebook. Penelitian ini menggunakan metode kualitatif dengan tipe studi fenomenologi, penentuan informan pada penelitian ini di tentukan dengan menggunakan teknik purposive sampling, dalam mengolah data penelitian ini menggunakan teknik filling system, Metode Filling System adalah metode dimana peneliti merasa data yang telah terkumpulkan sudah cukup maka dilakukan analisis. Hasil penelitian menunjukan bahwa delapan dari tiga belas informan tidak mampu mengontrol diri ketika mengakses facebook, sedangkan lima informan lainya mampu mengontrol diri ketika mengkases facebook. mereka yang tidak mampu mengontrol diri dalam penggunaan facebook cenderung tidak dapat mengontrol perilakunya dalam mengakses facebook seperti ketika menulis status mereka masih menggunakan Bahasa-bahasa yang tidak baik, dan mereka tidak meninjaui kembali apa yang mereka tuliskan di facebook mereka, mereka juga masih mengunggah foto yang kurang baik yaitu foto dengan tidak memakai hijab.
\end{abstract}

Kata Kunci : Kontrol Diri, Siswa, Facebook.

\section{PENDAHULUAN}

Dunia pendidikan saat ini adalah lembaga yang melakukan transfer ilmu pengetahuan dan bukan hanya itu sekolah juga menjadi tempat bimbingan kepada siswa terutama dalam aspek perilaku. Sebagaimana kita ketahui bahwa dunia pendidikan merupakan salah satu hal yang sangat penting dalam kehidupan ini, dengan adanya pendidikan maka akan lahirnya generasi-generasi penurus bangsa yang hebat.

Manusia adalah makhluk sosial, pada dasarnya sebagai makluk sosial manusia tidak bisa hidup seorang diri 
tanpa interaksi dengan orang lain. ${ }^{1}$ Dengan berkembangnya zaman yang semakin modern Adanya kehidupan yang semakin modern, dengan segala kecanggihan ilmu serta teknologi dan komunikasi yang semakin maju dan berkembang ini memberikan sumbangsih terhadap kelancaran kehiduapan manusia.

Keinginan untuk memiliki hubungan dengan orang lain ini pada umumnya sangat besar ketika manusia berada pada tahap perkembangan remaja. Penggunaan ini internet saat ini tidak hanya digunakan oleh orang dewasa saja, tetapi para penikmat internet juga berasal dari kalangan remaja, bahkan sampai anak-anak.

Di era modern ini, teknologi semakin maju. Tidak dapat dipungkiri hadirnya internet semakin dibutuhkan dalam kehidupan sehari-hari, baik dalam kegiatan sosial, pendidikan, bisnis, dan sebagainya, kemajuan teknologi dan informasi serta semakin canggihnya perangkat-perangkat yang diproduksi oleh industri seperti menghadirkan "dunia dalam genggaman". ${ }^{2}$ Di era moderen ini internet sudah menjadi suatu kebutuhan bagi masyrakat, dengan adanya internet akan membawa dampak yang positif dan akan berdampak negatif pula hal tersebut tergantung pengunannya dalam mengatur mengunakan internet.

Saat ini banyak sekali orangorang yang tidak bisa lepas dari Smartphone nya, terlebih lagi banyak fitur menarik yang ditawarkan oleh Smartphone salah satunya media social

1 Faizah, lalu muchsin effendi, psikologi dakwah, kencana : Jakarta, h. 39

${ }^{2}$ Rulli Nasrullah, Media Sosial (bandung: Simbiosa Rekatama Media 2017) h.1. (medsos) yaitu Facebook. Media social Facebook merupakan website yang berbasis jaringan sosial yang biasa digunakan untuk mencari teman dan berkomunikasi melalui internet. Dengan Facebook pengguna dapat saling berkirim pesan, menyimpan foto, dan sebagainya. $^{3}$

Facebook dalam kegiatan seharihari sangat penting bagi mereka yang menggunakannya terutama bagi anakanak muda / remaja. Ketika individu menggunakan Facebook untuk menggungkapkan atau mencurahkan segala hal yang terjadi dirinya maumpun memberikan informasi terkini terhadap orang lain, menunjukan bahwa orang tersebut memiliki keinginan untuk menampilkan diri dan mengungkapkan diri.

Penelitian ini siswa yang diteliti merupakan remaja awal yang berumur 12- 15 tahun, masa ini sebagai sebuah tahapan dalam kehidupan seseorang yang berada diantara tahap kanakkanak dengan tahap dewasa. Periode ini adalah ketika seseorang anak muda beranjak dari ketergantungan menuju kemandirian, otonomi, dan kematangan. ${ }^{4}$

Banyak perubahan yang dialami para remaja baik itu perubahan fisiologi, seksual, emosional dan kognitif. Ketika perubahan biologis terjadi pada remaja pada saat bersamaan juga terjadi perubahan kognitif. Remaja yang sedang mengalami perubahan kognitif akan mengembagkan suatu kemapuan berpikir abstrak, menemukan cara untuk berpikir tentang masalah hubungan, memahami cara-cara baru

3 Alif Harsan, Bengkel Facebook (jakarta: kawah media 2009) h. 133

${ }^{4}$ Kathryn Geldard, dan David Gelda, Konseling Remaja (Yogyakarta: Pustaka Belajar 2011) h. 5. 
mengolah informasi, dan belajar berpikir secara kreatif dan kritis. ${ }^{5}$ Usia remaja diharapkan telah memiliki kontrol diri yang baik agar dapat memilih dan mempertimbangkan halhal positif maupun hal-hal negative, dan dapat menggunakan media sosial Facebook sesuai kebutuhan.

Facebook tetap menjadi media sosial yang paling digemari di dunia. Hal ini terlihat dari jumlah penggunanya yang terus meningkat. Mengutip Statista pada kuartal I-2019 jumlah pengguna aktif Facebook per bulan (active user) sudah mencapai 2,38 miliar. Angka ini meningkat $8 \%$ jika dibandingkan jumlah pengguna aktif bulanan di kuartal IV-2018 sebanyak 2,32 miliar. Masih menurut statista, hingga April 2019 pengguna Facebook terbanyak berasal dari India, jumlahnya 260 juta pengguna. dan Indonesia mendudukin peringkat ke 4 dengan jumlah pengguna masing-masing 120 juta user. ${ }^{6}$

Setidaknya 71 persen remaja dengan rentang usia 13 hingga 17 tahun masih menggunakan jejaring sosial tersebut. Bahkan, 41 persen di antaranya mengaku bahwa Facebook adalah situs yang paling sering mereka kunjungi.? Jadi dapat dikatakan para remaja memiliki andil besar dalam penggunaan perkembangan Facebook. Facebook telah memberikan kemudahan bagi

${ }^{5}$ Ibid, h. 10.

${ }^{6}$ https://www.cnbcindonesia.com/tech/2019 0716112658-37-85252/india-jadi-penggunafacebook-terbesar-ri-urutan-berapa $\quad(01 \quad$ November 2019 13.38 WIB).

${ }^{7}$ Fatimah Kartini Bohang, "Facebook Masih DidominasiRemaja,BukanOrangTua",kompas.Com1 0april2015.https://tekno.kompas.com/read/2015/04/1 0/13100087/Facebook.Masih.Didominasi.Remaja.B ukan.Orang.Tua. (01 Maret 2019 10.26 WIB). penggunanya terutama siswa dalam berteman, dalam Facebook orang-orang dapat dengan mudah menjalin pertemanan.

Allah dengan kuasa Nya menciptakan manusia beraneka ragam, tidak ada dua orang yang mirip dalam segi apapun walaupun merupakan kakak adik atau saudara kembar. Allah menciptakan setiap hamba dengan berbagai keunikannya dengan tujuan untuk saling mengenal, saling toleransi dan menghargai, serta saling berinteraksi secara islami. Sesuai dengan firman Allah dalam QS Al Hujarat Ayat 13 :

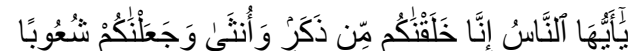

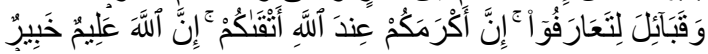

"Sesungguhnya Kami menciptakan kamu dari seorang laki laki dan seorang perempuan dan menjadikan kamu berbangsa bangsa dan bersuku suku supaya kamu saling kenal mengenal".

Facebook juga berfungsi sebagai sarana berbagi informasi dengan teman, sebagai sarana diskusi belajar dengan teman dan bisa memanfaatkan fitur lainnya seperti yang telah Facebook sediakan salah satunya fitur mengunggah gambar atau foto, dan juga sebagai sarana menemukan teman baru, dan sebagainya.

Namun masih banyak remaja yang mengunakan Facebook untuk halhal yang tidak penting, seperti beberapa siswa di MTsN Bustanul Huda yang menggunakan Facebook untuk memposting tentang kegiatan pribadinya, curhatan, serta foto-foto bersama teman-temannya. Karena pola pikir yang dibangun remaja saat ini adalah Semakin aktif seorang remaja di 
media sosial maka dianggap semakin keren dan gaul.

Permasalahan yang terjadi saat ini dimana para remaja yang seharusnya mereka lebih banyak menghabiskan waktunya untuk belajar dan mengerjakan hal-hal yang bermanfaat, namun fenomena yang terjadi saat ini dimana para remaja yang lebih sering menghabiskan waktunya dengan bermain sosial media.

Berdasarkan fenomena diatas peneliti menarik untuk melakukan penelitian dengan mengambil judul "Kontrol diri siswa dalam penggunaan Facebook di MTsN Bustanul Huda". Salah satunya seperti siswi yang biasa dipanggil Lia ini mengaku sering aktif pada akun social media Facebook ketimbang akun lainya dikarena kan banyak anak-anak seusianya yang menggunakan Facebook dan cara penggunaan Facebook tidak ribet dan tidak boros kuota internet, tentu Facebook sangat cocok digunakan bagi siswa yang belum memiliki penghasilan sendiri. dalam wawancara Lia mengatakan pada peneliti bahwa ia menggunakan Facebook untuk posting kegiatan hari-harinya berupa foto dan status.

\section{METODE}

Jenis penelitian ini adalah penelitian lapangan (field research) dimana peneliti akan mencari dan menemukan data-data hasil penelitian langsung terjun kelapangan. ${ }^{8}$ Penelitian ini menggunakan pendekatan kualitatif dengan tipe studi fenomenologi, pendekatan kualitatif adalah penelitian

${ }^{8}$ Sugiyono, Metode Penelitian Kuantitatif Kualitatif dan $R \& D$ (Bandung: CV. Alfabeta, 2012), h. 9. yang bermaksud untuk memahami fenomena tentang apa yang dialami oleh subjek penelitian misalnya perilaku, persepsi, motivasi, tindakan secara holistik dan dengan cara deskripsi dalam bentuk kata-kata serta bahasa pada sutau konteks khusus yang alamiah dan dengan memanfaatkan berbagai metode alamiah. Penelitian ini dilakukan di MTsN Bustanul Huda, Sungai Lueng Langsa.

Dalam penelitian ini peneliti menggunakan purposive sampling untuk mengambil sampel. Teknik purposive sampling ini orang-orang yang diseleksi atas dasar kriteria-kriteria tertentu yang dibuat periset berdasarkan tujuan riset. Sedangkan orang-orang dalam populasi tidak sesuai dengan kriteria yang sudah disediakan oleh peneliti tidak dijadikan sampel. ${ }^{9}$

Sumber data penelitian ini nantinya terbagi menjadi dua, yakni sumber dan primer dan sumber data sekunder dimana sumber data primer yang menjadi data awal atau pokok dalam penelitian ini. Dalam buku Lexy J. Moleong disebutkan bahwa sumber data primer adalah sumber data berupa kata-kata dan tindakan, sumber data tertulis. ${ }^{10}$ Sedangkan data sekunder adalah data yang diperoleh lewat pihak lain dan tidak langsung diperoleh oleh peneliti dari subyek penelitiannya. ${ }^{11}$ Sumber data primernya adalah para siswa MTsN Bustanul Huda. Sedangkan sumber sekundernya adalah buku-buku

${ }^{9}$ Racmat Kriyantono, Teknik Praktis Riset Komunikasi, (Jakarta: Kencana, 2006), h. 158.

10 Lexy J. Moleong, Metode Penelitian Kualitatif, (Bandung: PT. Remaja Rosdakarya, 2002), h. 157.

${ }^{11}$ Saifuddin Azwar, Metode Penelitian, (Yogyakarta: Pustaka Pelajar, 1999). 
atau referensi yang terkait dengan penelitian.

Metode yang digunakan untuk mengelola data kualitatif adalah dengan menggunakan metode Filling System. Metode Filling System adalah metode dimana peneliti merasa data yang telah terkumpulkan sudah cukup maka dilakukan analisis. Data hasil observasi akan dianalisisi dengan membuat kategori-kategori tertentu atau domaindomain tertentu. Setelah itu data diinterprestasi dengan memadukan konsep-konsep atau teori-teori tertentu. ${ }^{12}$

\section{HASIL TEMUAN DAN PEMBAHASAN}

\section{Gambaran Umum MTsN Bustanul Huda}

Penelitian ini di lakukan di Madrasah Tsanawiyah Bustanul Huda, sekolah ini beralamatkan di jalan Banda Aceh - Medan Km. 4 Sungai Leueng Langsa Timur Kota Langsa, provinsi Aceh. Sekolah ini dipimpin oleh ibu Rohani, S.Ag selaku kepala sekolah di MTsN Busatanul Huda. Status Madrasah saat ini (Terakreditasi Peringkat " $\mathrm{B}$ " dengan nilai 85 + dari BAN (Badan Akrediatasi Nasional) dan Kanwil Depag Propinsi Aceh Darussalam Tahun Pelajaran 2013.

MTsN BUstanul Huda sendiri awalnya berdiri pada 02 Juli 2002, sekolah ini memiliki luas tanah 5.194.7 M2 dan luas bangunan 5.04 M2. MTsN Bustanul Huda memiliki 7 ruang belajar. Jumlah siswa yang menempuh pendidikan di MTsN Bustanul Huda adalah 175 siswa dengan total guru 21 (

${ }^{12}$ Racmat Kriyantono, Teknik Praktis Riset Komunikasi... ,h. 199
8 PNS dan 13 Non PNS) dan total pegawai 4 ( Non PNS).

\section{Kontrol diri Siswa dalam Penggunaan Facebook}

Dari penelitian yang dilakukan kontrol diri adalah suatu kemampuan mengendalikan pikiran dan tindakan agar dapat menahan dorongan dari dalam maupun luar sehingga dapat bertindak dengan benar. Kontrol diri membantu seseorang mengendalikan perilaku mereka, sehingga mereka dapat bertindak benar berdasarkan pikiran dan hati nurani mereka. Ini merupakan mekanisme internal yang sangat berpengaruh yang mengarahkan sikap moral seseorang sehingga pilihan yang mereka ambil tidak hanya aman tetapi juga bijak. ${ }^{13}$

Berdasarkan penelitian serta observasi pada akun facebook yang telah dilakukan oleh peneliti, delapan dari tiga belas informan tidak memenuhi aspek kontrol diri yaitu aspek kontrol perilaku, kontrol kognitif, dan kontrol dalam mengambil keputusan. lima siswi yang memiliki kontrol diri dalam penggunaan facebook adalah SV, TW, FH, NA, PM, sedangkan delapan siswi yang tidak mampu mengontrol diri ketika mengakses facebook adalah KM, NL , JK, EN, NZ, IN, AF, GT.

a. Memiliki Kontrol diri (mampu mengontrol diri)

Pada Pengendalian diri informan yang tidak memiliki aspek kontrol perilaku atau tidak mampu mengontrol perilakunya

13 Zubaedi, Desain Pendidikan Karakter, (Jakarta : kencana) cet. 1, 2011, h. 61 
hal ini dibuktikan ketika mereka mengupdate status, menulis caption, dan menulis komentar tanpa menyelekasi atau meninjau kembali kata-kata yang mereka gunakan, mereka langsung menuangkan apa yang mereka fikirkan dan mereka rasakan, mereka tidak memikirkan baik buruknya tulisan yang mereka tulis pada akun facebook mereka, mereka juga masih menggunakan Bahasa yang tidak baik saat mengakses facebook baik itu dalam menulis status, caption pada foto, maupun komentar, hal ini serupa dengan hasil pengamatan peneliti pada akun ke delapan informan tersebut.

Pada pengendalian diri informan yang tidak memiliki aspek kontrol kognitif dapat dilihat dari ketidakmampuan informan mengelola informasi yang informan peroleh sehinggga informan tidak mampu melakukan penilaian dengan berbagai pertimbangan baik itu dari hukum agama, adat, hukum masyarakat, dan lain-lain. Dari hasil penelitian dapat dilihat bahwa para 8 dari 13 informan tidak mampu mengotrol kognitifnya, hal ini dapat dilihat dari pengetahuan atau informasi tentang Facebook yang mereka miliki, mereka masing mengupload foto yang tidak baik yaitu foto yang tidak menggunakan hijab, sehingga dapat di katakana bahwa informan tidak mampu menggunakan akun Facebook mereka dengan sebaikbaiknya melalui informasi yang mereka peroleh. mereka juga menganggap bahwa Facebook adalah hal yang penting.
Pengendalian diri informan pada aspek kontrol dalam mengambil keputusan, informan tidak mampu mengontrol diri dalam mengambil keputusan dapat dilihat dari kemampuan informan untuk memilih hasil atau suatu tindakan berdasarkan pada suatu yang diyakini atau disetujui oleh informan. Dari hasil penelitian peneliti menemukan bahwa delapan dari tiga belas informan tidak mampu mengontrol diri mengambil keputusan, dah hal ini dilihat bagaimana informan tidak dapat menyeimbangkan antara dunia maya dan kehidupan asli mereka, hal ini dapat di buktikan ketika berkumpul dengan teman para informan mengakses Facebook dan informan berserta teman-teman asik untuk memainkan handphone mereka masing-masing, ini membuat interaksi sosial secara langsung (tatap muka) berkurang karena informan tidak mampu membuat keputusan yang baik.

b. Tidak memiliki Kontrol diri (tidak mampu mengontrol diri)

Lima dari tiga belas informan yang lainnya memiliki kontrol diri atau mampu mengontrol dirinya, hal ini dibuktikan pada aspek kontrol perilaku ketika mereka mengupdate status, menulis caption, dan menulis komentar menyelekasi atau meninjau kembali kata-kata yang mereka gunakan, dan dalam bermedia sosial mereka juga masih menggunakan Bahasa yang baik hal ini serupa dengan hasil pengamatan peneliti pada akun ke lima informan tersebut. 
Para informan juga dalam aspek kognitif juga mampu mempertimbangkan dan menyeimbangkan antara keinginan dengan hukum agama, dan adat, salah satu contohnya dalam mengupload foto yang mereka memngupload foto yang menggunakan hijab serta foto-foto yang berisi kata-kata motivasi dan yang lainnya, mereka juga tidak menganggap bahawa facebook adalah hal yang penting baginya.

Pada aspek kontrol dalam mengambil keputusan ke lima informan ini dapat memutuskan dan menyeimbangkan kehidupan sosial antara facebook dan dunia nyata, mereka mampu ketika berkumpul dengan teman-teman mereka melakukan interaksi sosial secara langsung tidak terpaku pada handphone mereka, dan mereka mengatakan terkadang ada mengakses facebook ketika berkumpul dengan teman namun itu tidak berlebihan dan masih dalam batas wajar. sehingga dapat dikatakan bahwa ke lima informan ini memiliki aspek kontrol dan mampu mengontrol diri dalam mengakses facebook, baik itu aspek kontrol perilaku, kontrol kognitif, dan kontrol keputusan.

Kajian media sosial yang dilakukan oleh Erik Qualman dalam bukunya Socialnomics How Social Media Transforms The Way We Live and Do Business (2010). Ia pernah meneliti tentang dampak Facebook bagi kepribadian seseorang. Qualman pernah mengungkapkan 2 dampak dari media sosial yakni preventative behavior dan braggadocian behavior. Secara keseluruhan informan yang mampu mengontrol dirinya dengan baik dapat di katakana sebagai Preventative behavior. Preventative behavior diumpamakan dengan "live your life as if your mother is watching". Kalimat itu menunjuk pada orang yang selalu update status di media sosial facebook. Orang yang masuk dalam tipe ini adalah individu yang selalu berhati-hati dalam mem-post status, meng- upload gambar. Itu disebabkan karena apa yang dilakukannya dapat diketahui oleh orang lain dan dapat memengaruhi citra mereka. Mereka yang termasuk kelompok ini biasanya berpikir ulang untuk melakukan hal-hal yang berhubungan dengan media sosial karena seluruh dunia memperhatikan

(termasuk mungkin ibu mereka yang sebenarnya).

Sedangkan informan yang tidak mampu mengontrol dirinya dengan baik dapat dikatakan Braggadocian behavior. Braggadocian behavior jika ditinjau secara bahasa berasal dari kata braggart (pembual atau penyombong). Tipe orang dengan perilaku itu sangat sering update status sangat sering. Orang tersebut berusaha memberitahukan bahwa dirinya sedang melakukan sesuatu yang dianggap keren. Bahkan biasanya, orang-orang ini juga sering mengupload foto mereka dengan gaya narsis di tempat-tempat yang menurut mereka layak untuk diketahui orang lain. Mereka 
beranggapan, dengan cara seperti itu, mereka akan dianggap eksis. ${ }^{14}$

\section{SIMPULAN}

Berasarkan hasil penelitian dan pembahasan, maka dapat ditarik kesimpulan sebagai berikut :

1. Dari hasil penelitian diperoleh kesimpulan bahwa delapan dari tiga belas informan tidak mampu mengontrol diri dalam penggunaan facebook, kontrol diri tersebut meliputi aspek kontrol perilaku, kontrol kognitif, dan kontrol pengambilan keputusan. Sedangkan lima informan lainya mampu mengontrol dirinya dalam penggunaan facebook.

2. Informan yang tidak mampu mengontrol diri mereka cendenrung tidak dapat mengontrol perilakunya ketika mengakses facebook, mereka ketika mengakses facebook tidak meninjau kembali kata-kata yang mereka tulis, mereka hanya menuliskan apa yang mereka rasa tanpa memikirkan akibat baik dan buruknya tulisan mereka pada akun facebook mereka dan mereka menulis menggunakan Bahasa yang tidak baik dan kurang sopan dalam bermedia sosial. Informan yang tidak mampu mengontrol diri, ketika mengupload foto mereka masih mengupload foto yang kurang baik salah satunya foto yang tidak menggunakan jelbab.

14 Nurudin, Media sosial sebagai katarsis mahasiswa, Vol. 7 No. 2 (2015) h. 95.
Informan yang tidak memiliki kontrol kognitif mereka cenderung tidak mampu mengelola informasi yang mereka peroleh, sehingga mereka tidak mampu menggunakan facebook dengan sebaik-baiknya hal ini di buktikan dengan motif informan dalam mengupload atau mengupdate status yaitu mereka berharap untuk diperhatikan dan berharap untuk di puji, perilaku ini disebut dengan katarsis. Informan yang tidak memiliki kontrol diri yang baik mereka cenderung tidak mampu mengontrol diri dalam mengambil keputusan, mereka tidak mampu menyeimbangkan antra dunia nyata dengan dunia maya. mereka cenderung lebih aktif di facebook ketimbang berinteraksi langsung dengan teman-temanya, hal ini di buktikan ketika informan berkumpul dengan temantemannya mereka tetap mengakses facebook.

3. Informan yang memiliki kontrol diri yang baik mampu mengontrol perilakunya saat mengakses facebook salah satunya adalah ketika mengakses facebook para informan tersebut menyeleksi kata-kata yang mereka tulis pada akun facebook mereka, dan saat mengakses facebook mereka menggunakan Bahasa yang baik. Informan yang memiliki kontrol diri yang baik mampu mengelola akun facebooknya pada hal-hal yang baik, seperti mengupload foto diri. Di mana yang kita tahu bahwa foto diri atau selfie sudah 
menjadi hal yang trend di zaman sekarang namun infoman yang memiliki kontrol diri yang baik mereka mampu membatasi diri mereka, untuk tidak mengupload foto yang tidak baik salah satunya seperti foto yang tidak memakai jelbab. Informan yang memiliki kontrol kognitif dalam mengakses facebook mereka mampu mengelola informasi yang mereka peroleh kemudian melakukan penilaian dengan berbagai pertimbangan baik itu dari hukum agama, adat, hukum masyarakat, dan lain-lain. mereka mampu menggunakan Facebook dengan sebaik-baiknya melalui informasi yang mereka peroleh. Mereka menggunakan Facebook masih dalam kategori wajar dan tidak berlebihan mereka juga menganggap Facebook bukanlah hal yang penting. Mereka pun dapat mengontrol diri dalam mengambil keputusan dalam mengakses facebook, hal ini dapat dilihat ketika informan dapat menyeimbangkan antara dunia maya dengan dunia nyata. Mereka mampu mengambil keputusan untuk lebih aktif dalam berinteraksi secara langsung ketimbang berinteraksi dengan dunia maya, hal ini dibuktikan ketika informan berkumpul dengan teman-teman mereka yang memiliki kontrol diri yang baik mampu memilih keputusan untuk berinteraksi dengan teman-temannya ketimbang mengakses facebook.

\section{DAFTAR PUSTAKA}

Alif, H. (2009). Bengkel Facebook. Jakarta: Kawah Media.

Bohang, F. K. (2015). "Facebook Masih Didominasi Remaja, Bukan Orang Tua",kompas. Com10april2015.https://tekn o.kompas.com/read/2015/04/ 10/13100087/Facebook.Masih .Didominasi.Remaja.Bukan. Orang.Tua.

Faizah, \& Effendi, L, M. (2009). Psikologi Dakwah. Kencana : Jakarta.

Kathryn, G., \& Gelda, D. (2011). Konseling Remaja. Yogyakarta: Pustaka Belajar.

Moleong, L. J. (2002). Metode Penelitian Kualitatif. Bandung: PT. Remaja Rosdakarya.

Nurudin. Media sosial sebagai katarsis mahasiswa, Vol. 7 No. 2 (2015).

Racmat, K. (2006). Teknik Praktis Riset Komunikasi. Jakarta: Kencana.

Rulli, N. (2017). Media Sosial. Bandung: Simbiosa Rekatama Media.

Saifuddin, A. (1999). Metode Penelitian Yogyakarta: Pustaka Pelajar.

Sugiyono. (2012). Metode Penelitian Kuantitatif Kualitatif dan $R \mathcal{E}$ $D$. Bandung: CV. Alfabeta.

Zubaedi. (2011) Desain Pendidikan Karakter. Jakarta : kencana. 